\title{
The Role of Value Creation Strategy of Marine Products for Sustainable Competitive Advantage in Asean Economic Community 2015
}

\author{
Yenny Maya Dora \\ Lecturer Faculty of Business and Management Widyatama University, Students Doctoral Program in Business and \\ Management Padjadjaran University, Duo - Indonesia; Yenny.maya@widyatama.ac.id
}

\section{Doi:10.5901/mjss.2015.v6n5s5p249}

\section{Abstract}

The purpose of this paper to find out how the role of value creation strategies for competitive advantage in the small and medium industrial marine products. Resulting in value creation strategies for competitive advantage seafood products industry in the ASEAN Economic Community by 2015. The problems of this paper to analyze the information obtained from interviews and gave questionnaires carried out in the Small and Medium Industry employers. The approach used is using SWOT analysis method to get the right strategy for value creation on seafood products. The implications that will be obtained from this study is the value creation strategies for marine products in order to remain able to win the competition in the Asean Economic Community in 2015.

Keywords: strategy of value creation, Small and Medium Industry, marine products, SWOT Analysis and the ASEAN Economic Community.

\section{Introduction}

Marine Resources Indonesia is the source of life and livelihood (source of food, energy and livelihood) that incessantly, from generation to generation if done correctly pemanfaatannnya sustainably; People's economy based on marine resources can be improved in an effort to improve the welfare of the community;

Contains marine plant and animal species are countless. All creation is provided a barn that is very much on the chemical compounds unknown on the plains of additional molecules on a variety of active biological activity such as antibacterial, anti-cancer, anti-inflammatory, anti-oxidative, and others.

Enhance the growth of marine resource-based industries are strong and resilient in order to create value growth for the economy of the people and the national economy. Improve business and economic activities utilization of natural resources of small and medium-scale enterprises to improve the economy of the people and encourage linkages with large enterprises. The government should encourage the national private industry play in the less daring sea exploration. Enhancing the role of government to be able to build SOE sea exploration industry. Monitoring and supervision of the activities of exploration and production in order to ensure optimal utilization of resources and sustainable for the benefit of the nation. and. Meet and complete equipment and devices SDM Island States.

Ministry of Trade of the Republic of Indonesia in the book "Towards the ASEAN Economic Community", states; In order to improve export competitiveness and encourage economic integrity of ASEAN towards a single market for goods, services and investment as well as a single production-based ASEAN, trade and kepabean necessary mechanisms, processes, procedures and information flows related to the simple, harmonized and standardized. With the trading facility will be expected to create an environment that is consistent, transparent and predictable for international trade transactions so as to promote trade and business activities, including small and medium enterprises, as well as saving time and reducing transaction costs.

But the similarity of the main export products are one cause of the share of intra-ASEAN trade only between 20-25 percent of total ASEAN trade. Indonesia needs to do in adding value to their product that has its own characteristics with products from other ASEAN countries. (Ministry of Commerce of the Republic of Indonesia in the book the book "Towards the ASEAN Economic Community).

According to Vargo, Akaka, (2009, creation of value extending beyond the boundaries of individual creation or post Systems Services And Value Being, the process of translating the Sustainable Yang Yang involves Dynamic Systems Service System.

To remain competitive in this new environment and to stay abreast of consumer expectations, the business of 
marine products should update their products and their techniques continuously. They also must be able to seize the opportunities offered by the world.

Based on the above this paper focuses on the role of value creation strategy marine products for sustainable competitive advantage in the ASEAN Economic Community in 2015

\section{Literature Review}

\subsection{Marine Products}

Sea has a variety of human resources that can be utilized, among others, as a source of mineral and vegetable resources.

a. As Mineral Resources

1. Salt for cooking purposes.

2. Carbonates taken from countryman moss (potash).

3. Phosphate derived from bones of fish and fish food bird droppings can be used for fertilizer.

4. Offshore oil resources can be found in the Java Sea, Sumatra, Malacca, the Celebes Sea, and South China Sea.

b. As Vegetable Resources

1. Seaweed is cultivated in shallow sea area can be used for materials to make jelly.

2. Plant ocean for fish food, ie plankton, nekton, phytoplankton and benthos.

3. The Marine Fish Works For Fish Consumption: Baronang, Yellow Tail, shark, snapper, goats, grouper, Cakes, Marlin / voyage, Pari, mackerel, Teri and Cob

Life at sea was not much different from the situation on the ground. In the sea there is also a living being composed of marine plants and marine animals.

\subsection{Marine life can be divided into three categories, namely plankton, nekton, and benthos.}

\subsubsection{Plankton}

Plankton is the union of the bodies of animals and one-celled plants. Plankton can not move themselves, but living with a float on the surface or near the surface of the sea water including passive pelagic group.

1) Mikroplankton, consisting of:

a) radiolarians (animal) and diatomaceous (plants) that have order S1O2,

b) foraminifera (animals) that have a framework of $\mathrm{CaCO}$.

2) Phytoplankton

Phytoplankton is plankton species of plants that live at depths of no more than $100 \mathrm{~m}$, with respect to the need for sunlight for photosynthesis.

\subsubsection{Nekton}

Nekton is a combination of animals that can swim especially marine animals. Nekton including pelagic groups are actively engaged, such as fish, squid, octopus, and others.

\subsubsection{Benthos}

Benthic marine organisms whose life is bound in the seabed. From this group there is life crawling on the ocean floor, such as marine worms, oysters, mussels, but some are attached to the seabed, such as seaweed, algae, and sponges.

\subsection{Value Creation}

Here is the definition of value creation in the opinion of the experts who have conducted research related partnered with the creation of value:

Bowman and Ambrosini (2007), "is the value creation process of value creation from the perspective of the company and the level of business strategy by considering whether additional activities can be tightly or 
loosely." Bowman and Ambrosini (2007, P.), "the creation of value is the value creation process from the perspective of corporate and business level strategy by considering whether this activity can be tightly or loosely coupled." Lepak, et al., (2007, P . 180-194), "value creation is considered as a dynamic process of creating a product or service that is valuable to be subjectively appreciated by the user based on user criteria of value." Pitelis, (2008, P. 6), "adding value in this case ' added value 'equals' value creation' and the feasibility of additional perceived done through price reduced or increased differentiation. "Vargo and Akaka (2009, p. 39) is the process of creating value-use of these resources.

Grönroos and Ravald (2010, P.7), "Value creation is the process of creating the value-in-use of these resources." Chatain \& Zemsky (2011, P.35), "value creation emerged as a result of strategic interaction." Lautermann (2013, P.192), "the creation of value as a way conducive to achieving a good life, various kinds of goods - goods that can be traded to make their materials or goods aesthetic, cultural, spiritual and material - produced by subsistence activities such as gardening or community work, must be taken into account".

\subsection{Definition of a SWOT analysis}

SWOT is the strength (Strenghts), weakness (Weakness), opportunities (Opportunities) and threats (Threats) of the external environment.

According Jogiyanto (2005: 46), SWOT be used to assess the strengths and weaknesses of the resources of the company and external opportunities and challenges faced.

According to David (Fred R. David, 2008.8), All organizations have strengths and weaknesses in the functional areas of business. No company is as strong or weak in all business areas. Strengths / weaknesses, coupled with the opportunities / threats from external and clear mission statement, the basis for goal setting and strategi.Tujuan and strategies set with the intention of utilizing the internal strength and overcome weaknesses.

Here is an explanation of SWOT (David, Fred R., 2005: 47), namely:

\subsubsection{Strength (Strenghts)}

Strength is the resources, skills, or keungulan-keungulan else related to the company's competitors and market needs can be served by a company that is expected to be served.Strength is a special competition which gives the company a competitive advantage in the marketplace

\subsubsection{Weakness (Weakness)}

A drawback is the limited or lack the resources, skills, and capabilities that effectively inhibit the performance of the company. The limitations daoat form of facilities, financial resources, management capabilities and marketing skills can meruoakan source of weakness company.

\subsubsection{Opportunities (Opportunities)}

Opportunity is important that competitive situation in an enterprise environment.Tendency - important trends are one source of opportunity, such as the change in technology and the growing relationship between the company and the buyer or supplier a picture opportunities for the company.

\subsubsection{Threats (Threats)}

Threats are important situations of unfavorable in an enterprise environment. The threat of a major nuisance for current or desired position of the company. The existence of government regulations that are new or revised may represent a threat to the company's success.

\subsection{SWOT functions}

According to Ferrel and Harline (2005), the function of the SWOT analysis is to obtain information from the analysis of the situation and separating the internal issues (strengths and weaknesses) and external issues (opportunities and threats).

The SWOT analysis will explain whether the information indicated something that will help the company achieve its goal or provide an indication that there are obstacles to overcome or minimized to meet the desired entry. SWOT analysis 
can be used in various ways to improve the analysis in the determination of business strategy. Generally that is often used is as a framework / guidelines systematically in discussions to discuss conditions basic alternatives which may be considered firm.

\subsection{SWOT matrix}

According Rangkuti (2006), Matrix SWOT shows clearly how the opportunities and external threats that facing by the company can be adapted to the strength of its and weaknesses. This matrix can produce four sets of strategic alternative possibilities.

The following is a description of the SWOT matrix above:

1. SO Strategy (Strength and Oppurtunity). This strategy is based on the company's way of thinking, is to harness the power to seize and exploit the opportunities of - magnitude.

2. ST Strategies (Strength and Threats). Strategy in using the power of the company to overcome the threat.

3. Strategy WO (Weakness and Oppurtunity). This strategy is based on exploiting existing opportunities by minimizing weaknesses.

4. WT Strategies (Weaknesses and Threats). This strategy is based on activities that are defensive and try to minimize weaknesses and avoid threats.

\section{Research Method}

SWOT matrix is used to match the results obtained on the IFE and EFE matrix (Rangkuti, 2003; Yuliawati, 2008). This matrix can produce four cells a possible alternative strategy, that strategy-Opportunity Strengths, Weakness-Opportunity strategy, strategy-Threaths Weakness and Threaths Strengths- strategy

\subsection{Data Collection}

Data collection was done by interview and questionnaire (questionnaire) to employers of marine products in the area of Cirebon. The interview and questionnaire (questionnaires) were processed and analyzed using SWOT analysis method.

\subsection{Data Processing}

This study using SWOT analysis method used to determine the value creation strategies for craft businesses chrocate and hand embroidery.

SWOT Analysis

a. Analysis Matrix Internal Factor Evaluation (IFE) and External Factor Evaluation (EFE) pairwise comparison technique used to collect data used to determine the weight of internal and external factors. This technique serves to compare each variable on the horizontal column with variable have on the vertical column.Weighting to each variable are compared using a scale of 1,2 , and 3.

Scale used indicates:

1. If external factors or internal to the line / horizontal strategically less important than the external and internal factors on the column / vertical

2. if the strategic factors external or internal to the line / horizontal equally important than external and internal strategic factor in the column / vertical

3. if the external and internal strategic factor on the line / horizontal equally strategically more important than the external and internal factors on the column / vertical.

Strategic weight of each factor obtained by me nentukan total value of each factor strategic to the overall number of strategic factors by using the formula: $\Sigma$ Scoring ranking / rating rating value at IFE matrix shows the level of factor strategic strengths and weaknesses which affect the value creation in business chrocate craft and hand embroidery Scoring ratings are based on the following information:

a. Grades 4, If the power factor is considered a big influence and if factors such weaknesses are minor flaws are considered a small effect.

b. Grades 3, if the power factor is considered to affect small and if factors such weaknesses are minor flaws are considered minor.

c. Value 2, If the power factor is considered a big influence and if factors such weakness is the main weakness is 
considered a small effect.

d. A value of 1 , if the power factor is considered to affect small and if factors such weakness is the main weakness is considered a big impact.

Rating on the scoring matrix based on the EFE chrocate craft business capabilities and hand embroidery in grabbing the opportunities that exist and the magnitude of the threat that could affect the existence of the craft business chrocate and hand embroidery.

Scoring ratings are based on the following information:

e. Grades 4, if the industry has a very good ability to seize these opportunities factors and factors such threats very weak influence on the industry.

f. Grades 3, if the industry has a good ability in reaching factors such opportunities and threats factors provide weak influence on the industry.

g. Value 2, If the industry has pretty good ability to achieve these faktorpeluang and threat factors provide a strong influence on the industry.

h. A value of 1 , if the industry does not have the ability either to seize these opportunities and the factors factor threats very strong influence on the industry.

b. Analysis Matrix Internal-External (IE) Values obtained from IFE and EFE matrix dimasukkaan into InternalExternal matrix to map the position of the company at this time (Yuliawati, 2008). Total score weighting matrix IFE in IE, placed on the $x$-axis and the total score weighting EFE on the $y$ axis. IE matrix is divided into three major parts which have different implications for strategy, namely (Yuliawati, 2008):

1. Which is in cell division I, II, or IV can implement strategies to develop and build (growth and build). Commonly used strategy is the intensive strategy (market penetration, market development, and product development) or integrative strategies (backward integration, forward integration and horizontal integration).

2. Which is in cell division III, V, or VII can implement strategies to maintain and preserve (hold and maintain). Commonly used strategy is market penetration and product development.

3. Which is in cell division $\mathrm{VI}, \mathrm{VIII}$, or IX, the strategy taking or releasing results (harvest or Divest). Commonly used strategy is the divestiture strategy, conglomerate diversification strategy and the strategy of liquidation.

\section{Discussion}

Tabel 4.1. Evaluation results Internal Environment Industry

\begin{tabular}{lccc}
\hline Strategic Factor & Weight & Rating & Scores strength \\
\hline - $\quad$ Product development workforce & .121 & 4 & .468 \\
- $\quad$ Raw material resources & .118 & 3 & .353 \\
- Knowledge of marine products & .109 & 2 & .325 \\
- The potential for a profitable investment & .107 & 1 & .324 \\
Weakness & & & \\
$-\quad$ Skills energy production & .101 & 4 & .303 \\
- Resources coaches & .099 & 3 & .293 \\
$-\quad$ Market information & .125 & 2 & .232 \\
- Skills coach & .106 & 3 & .213 \\
- Availability of capital & .134 & 1 & .128 \\
Total & 1 & & 2.641 \\
\hline
\end{tabular}

Source: Primary data is processed (2015)

Based on Table 4.1 it can be seen that there are four key factors that powers the business of marine products in support of the creation of value. The strength factors include the availability of product development manpower, raw material resources, knowledge of marine products and the potential for a profitable investment. Of the four factors, the availability of labor is a key factor of product development strengths has the highest score value of .468 with a rating worth 4 . This 
suggests that the availability of labor force design is the most influential factor in supporting the efforts of value creation.

There are five key elements of weakness factors that influence the creation of business value marine products include power production skills, resources trainers, market information, availability of capital, and institutional support. Availability of capital is a major weakness that has the most influence on the creation of value in the craft business chrocate. This is indicated by the score obtained from IFE matrix of .128 to 1. In accordance with the rating value delivered Tambunan (2003) that, weak capital owned marine product business people have a negative impact on the sustainability and development of the marine product business. The existence of a limited amount of capital, it would be difficult for an industry to meet the financing needs ranging from financing the production of raw materials, labor financing, or financing the production. Thus it takes the capital resources that can support both private and institutional capital to capital government agencies such as savings and loans, Rural Banks to ensure the sustainability of the marine products industry. In practice, also needed the support of local governments that regulate legislation and clear rules regarding the lending of capital for small and medium industries.

\subsection{Evaluation results External Environment Industry}

Identification by the external environment marine products business showed some influential factors consisting of opportunities and threats. These factors were then evaluated using External Factor Evaluation Matrix (EFE). By evaluating these factors, it can be determined that the appropriate strategy in the marine product business development. EFE Calculation results can be seen in Table 4.2

Table 4.2. Matrix Calculation Results External Factor Evaluation (EFE)

\begin{tabular}{lccc}
\hline Strategic Factors & Weight & Rating & Scores strength \\
\hline$-\quad$ Potential market & .130 & 4 & .523 \\
- Labor availability & .127 & 4 & .506 \\
- Developments in science and technology & .116 & 3 & .346 \\
- Cultural locals & .114 & 3 & .314 \\
- Local government support & .111 & 2 & .220 \\
Threat & & & \\
- Fluctuations in product prices & .112 & 2 & .336 \\
- Rules and regulations & .069 & 4 & .276 \\
- Rupiah exchange rate & .106 & 3 & .212 \\
- Similar entrepreneurs & .125 & 1 & .212 \\
Total & 1 & & 2.860 \\
\hline
\end{tabular}

Source: Primary data is processed (2015)

Based on identification of external factors, it is known that there are five factors that affect the chances strategic business value creation of marine products, the market potential, availability of labor, the development of science and technology. Of the five strategic factors such opportunities, market potential are the external factors that have the highest value score of .523 with a rating of 4 . This indicates that the potential market opportunities are very influential factor and can be used very well by the marine product business. By utilizing the opportunities good market potential, an industry would be able to survive in the global competition and encourage the development of the industry (Wrihatnolo, 2006). At the strategic factor threat, there are four factors were deemed threats will hinder the process of value creation in the business of marine products, among others, fluctuations in product prices, regulations and legislation, the rupiah, and entrepreneurs alike. Of the four factors, the type of entrepreneur is a threat factor which is considered very influential in the creation of business value marine products. This is consistent with a score of .212 EFE matrix with a rating of 1. Employers kind that occur will affect the stability of the marine product business performance both in terms of product marketing, so that the necessary effort to value creation can still compete with the kind of businessman.

\subsection{Alternative Industry Development Strategy}

From the calculation of IFE and EFE matrix, obtained the proper formulation strategies to be applied marine product 
business is product development strategy through the creation of value and market penetration strategies.

Priority Strategies marine product business value creation, having determined the corresponding relationships between each alternative is obtained, then weighted using Analytical Network Process to determine priority values of each alternative strategy. Each alternative strategy weighs different priorities. Basic selection value creation strategy that is based on the value of the weight that was adjusted. Based on the weighting results in Table 4.3, it can be seen an alternative sequence of strategies ranging from the highest to the lowest weighting.

Table 4.3. Weight Calculation Results Alternative Strategies

\begin{tabular}{clcc}
\hline No. & Alternative & Strategy & Weight \\
\hline 1 & Ties of cooperation with the industry development institute & (ST2) & .229 \\
2 & Cooperation with SME information service center & (SO3) & .190 \\
3 & Resource procurement coach marine products & (WO3) & .166 \\
4 & Develop and optimize business information service function & (WO1) & .147 \\
5 & Provision of integrated marketing center for the marine industry products & (WT1) & .089 \\
6 & The formation of business partnerships with other parties & (SO2) & .077 \\
7 & Development finance institutions industry & (WO2) & .063 \\
8 & Optimization of marketing performance with the use of technology & (SO1) & .023 \\
9 & The development of downstream industries & (ST1) & .017 \\
Total & & 1 \\
\hline
\end{tabular}

Source: Primary data is processed (2015)

From Table 4.3 it can be seen that the strategy of forming cooperative ties with an industrial development agency strategy with the highest weight value of .229. Conduct cooperative ties with the industrial development agencies would provide strong support to the business performance kelatan products through various aspects. Collaborated with industrial development agencies give a good impact in terms of quality improvement and quality of marine products (Assauri, 2004). By using this strategy, entrepreneurs marine products will support and guidance in developing the industry both from the aspect of funding, technology development and improvement of production systems. Improving the quality and the quality of marine products will increase the prospects for products in the market that will facilitate the marine product business in obtaining factors available opportunities. To execute these strategies necessary for an integrated movement between communities, industry and government are realized in the form of partnerships. Activities that can be done is to optimize the function of the central and local entrepreneurial organizations to support the efforts penginventarisasian potential of marine resources.

\section{Conclusions and Suggestions}

\subsection{Conclusion}

To remain competitive in this new environment era of AEC 2015 and to stay abreast of consumer expectations, the marine products business, must undertake product development and marine product processing techniques continuously. To be able to develop products, the availability of labor is a product development plays an important role in developing the types of marine products. They also must be able to seize the opportunities offered by the world by providing added value to the products and cooperating sedengan various parties in an effort to expand the marketing of their products.

With the globalization of markets, marine products should be they are obliged to operate in an increasingly competitive environment, both in terms of price as well as the development of new attributes, new markets, or new procedures.

\subsection{Suggestions}

The entrepreneurs of marine products should continue to be able to:Collaborate with other entrepreneurs such as: Employers clothes, shoes, bags, and hats. Doing the creation of value in marine products such as fish scales (for 
decoration clothes, scarf, hat, necklace), Leather Fish, Shellfish be decorated hats, shoes. Make processed marine products such as fish noodles taste, flavor shrimp, squid flavor, and taste; Chips taste of shrimp, squid, shellfish and fish, shellfish Sosi. Nuggets taste of fish, squid, shrimp, and scallops. Sausage flavor of fish, shrimp, squid and clams. Health products: drinks, and drugs.

\section{References}

AMIT1 * and Zott, "Value Creation in E-Business," Strategic Management Journal Strat. Mgmt. J., 22: 493-520 (2001) DOI: 10.1002 I smj.187

Andersson, Harri; Harju, Taneli; Larjomaa, Timo, "Value creation - it is time to get serious PPI; February 2002; 44, 2; ProQuest Agriculture Journals, pg. 33

Beatley, Timothy and David J Brower. 1994. An Introduction to Costal Zone Management. Washington DC Island Press.

Bowman, C. and Ambrosini, V. (2000), "Value creation versus value capture: towards a coherent definition of value in strategy", British Journal of Management, Vol. 11 No. 1, pp.1-15.

Cliff Bowman and Ve'ronique Ambrosini (2007), "Firm value and levels of Creation Strategy," Management Decision Vol. 45 No. 3, 2007, pp. 360-371

Christian Grönroos and Annika Ravald, "Service as business logic: implications for value creation and marketing," Journal of Service Management Vol. 22 No. 1, 2011, pp. 5-22 qEmerald Group Publishing Limited 1757-5818.

Christian Lautermann, "The ambiguities of (social) value creation: towards an extended understanding of entrepreneurial value creation for society", Social Enterprise Journal Vol.9 No. 2, 2013 pp. 184-202 q Emerald Group Publishing Limited 1750-8614

Dault, Adhiyaksa. 2008. Youth and Marine . Yogyakarta. Parama Aji image

David, Fred R., 2006. Strategic Management. Ten edition, Publisher Salemba Four,Jakarta

Dyson, RG 2004. Strategic development and SWOT analysis at the University of Warwick.European journal of operational research, 152 (3), 631-640.

Eggert and Ulaga, "Value Creation in the Relationship Life Cycle: A Quasi-Longitudinal Analysis," ESCP-EAP European School of Management Marketing Department 79, avenue de la République 75543 Paris Cedex 11 France

Gholami, "Value Creation Model through Corporate Social Responsibility (CSR),"International Journal of Business and Management Vol. 6, No. 9; September 2011

Getachew Abatekassa * and H. Christopher Peterson, "The Local Food Concept: Market Access through the Conventional Food Supply Chain", 18th Annual Forum and Symposium IAMA Conference Monterey, California, USA, June 2008

Fauzi Ahmad. 2004. Environmental and Natural Resource Economics Theory and Applications .Jakarta. Gramedia Pustaka Utama.

Foster, Robert J, "THE WORK OF THE NEW ECONOMY: Consumers, Brands, and Value Creation," Cultural Anthropology; November 2007; 22, 4; ProQuest Sociology pg.707

Giner, "New Avenues Of Value Creation In The Agro-Food Sector," TAD / CA / APM / WP (2008) 15 / FINAL

Hanif Mauludin, Taher Alhabsji, Syafii K., Zainul Arifin, "Market orientation, Learning Organization and Dynamic Capability as antecedents of Value Creation" IOSR Journal of Business and Management (IOSR-JBM) e-ISSN: 2278-487X, p-ISSN: 23197668. Volume 10, Issue 2 (May. - June 2013), PP 38-48 www.iosriournals.org .

Insch, "Triggers and processes of value creation in Australia's chicken meat industry," British Food Journal Vol. 110 No. 1, 2008, pp. 2641

Jogiyanto 2005, Strategic Information Systems for Competitive Advantage, Publisher Andi Offset, Yogyakarta.

José Ángel López Sánchez, María Leticia Santos Vijande, Juan Antonio Trespalacios Gutiérrez, "Value-creating functions, satisfaction and loyalty in business markets: a categorical variable approach using a robust methodology under structural equation modeling", Published Online: January 1, 2011, ๔ Springer Science + Business Media BV 2010

Maumbe Blessing, "The rise of South Africa's quick service restaurant industry", Journal of Agribusiness in Developing and Emerging Economies, Vol. 2 No. 2, 2012 pp. 147-166 r Emerald Group Publishing Limited 2044-0839DOI 10.1108 / 20440831211272607

Pirson, "Social entrepreneurs as the paragons of shared value creation? A critical perspective, "Social Enterprise Journal, Vol. 8 No. 1, 2012, pp. 31-48

Stefanie Bro"ring, L. Martin Cloutier, "Value-creation in new product development within converging value chains An analysis in the functional foods and nutraceutical industry,"British Food Journal Vol. 110 No. 1, 2008 pp. 76-97 q Emerald Group Publishing Limited 0007-070X

Ravald, A. (2010), "The customer's process of value creation", Mercati e Competetitivita ', Vol. 1 No. 1, pp. 41-51 (special issue on the 2009 Naples Forum on Service).

Ravald, Antika; Grönroos, Christian (1996), The value concept and relationship marketing, European Journal of Marketing [interactive source], Vol. 30, No. 2 [Referred on March 10, 2010], p19-30, Accessed at: <http://www.emeraldinsight.com>.

Rangkuti F. 2003. SWOT Analysis Techniques Dissecting the Business Case. PT. Gramedia Pustaka Utama. Jakarta.

Rangkuti, Freddy. (2006). SWOT Analysis Techniques Dissecting the Business Case. PT.Gramedia Pustaka Utama, Jakarta.

Rustiadi, Ernan et al. 2011. Planning and Development area, Jakarta.Crestpent Press.

Simona Bakutyte, Dainora Grundey, "Identifying the Gap in Value Creation at Universities: the Consumer's Perspective", Economics \& Sociology, Vol. 5, No. 1, 2012,pp. 96-110.

Stefanie Bro"ring, "Value-creation in new product development within converging value chains An analysis in the functional foods and 
nutraceutical industry," British Food Journal Vol. 110 No. 1, 2008, pp. 76-97

Tamer Madi, Zulkhairi Dahalin, Fauziah Baharom, "Towards A User Value Co-Creation Model Approach for Agile Web Development", Special Issue-Agile Symposium, Malaysia, ISSN 1013-5316; Coden: Sinte 8

Tarin, Robinson. 2004. Regional Planning. Jakarta Earth Literacy.

Vargo and Akaka: On value and value co-creation: A service systems and service logic perspective, "European Management Journal (2008) 26, 145- 152

Vargo and Akaka: Service-Dominant Logic as a Foundation for Service Science: Clarifications Service Science 1 (1), pp. 32-41, 2009 SSG

Zubac A, G Hubbard, Johnson WL (2010). The RBV and value creation: A managerial perspective . Eur. Bus. Rev. 22 (5): 515-538. 2 